\title{
THE HIMALAYAS: FROM MOUNTAIN BUILDING TO LANDFORM EVOLUTION IN A CHANGING WORLD
}

\author{
MONIQUE FORT \\ Department of Geography, GHSS (Case 7001) \\ Université Paris-Diderot, Sorbonne-Paris-Cité \\ CNRS UMR 8586 PRODIG \\ 5 rue Thomas Mann \\ F. 75205 PARIS Cedex 13 \\ E-mail: fort@univ-paris-diderot.fr
}

\begin{abstract}
The Himalayas are a living mountain mass, which, in addition to their rocks, landforms and processes, are the homeland of people who must continually adapt to their geodynamically very active, yet inspiring environment. We focus on the Himalayas of Nepal, one of the less developed countries in the world. This paper addresses different issues: mountain landform building, the role of current processes and natural hazards, and their interactions with a changing world, i.e. under the influence of economic development in a context of globalization and climate change.
\end{abstract}

Key words: Nepal Himalayas, geomorphic processes, natural hazards, global change

The Himalayan mountain building is a continuous process leading to the development of a variety of landforms depending on the time and spatial scales considered. In the long term, tectonic processes and rock uplift exert the main control on gross landform geometry, whereas in the medium and short terms climate parameters and fluvial incision control both slope evolution and sedimentary fluxes out of the mountains. Erosion work is mostly accomplished by landsliding, a major natural hazard that causes many human and economic losses each year. During the last decades, demographic growth, land use change and development of infrastructure have increased the vulnerability of the population to landslides. In this paper we focus on the Nepal Himalayas, one of the less developed countries in the world. We address different is- sues: mountain landform building, current geomorphic processes and natural hazards, and interactions with a changing world, i.e. under the influence of economic development in a context of globalization and climate change.

\section{THE MOUNTAIN LANDFORM BUILDING}

1.1. GEODYNAMIC CONTEXT OF THE HIMALAYAS The $2,500 \mathrm{~km}$ long Himalayas represent the southern limit of Tibet, the highest plateau on Earth. The mountain range itself is the result of collision between the Indian and Asian continents (Gansser, 1964; Valdyia, 1998). The Indian plate, broken apart from the old Gondwana continent, started drifting northward some 90 million years ago at a rate of $20 \mathrm{cma}^{-1}$. 


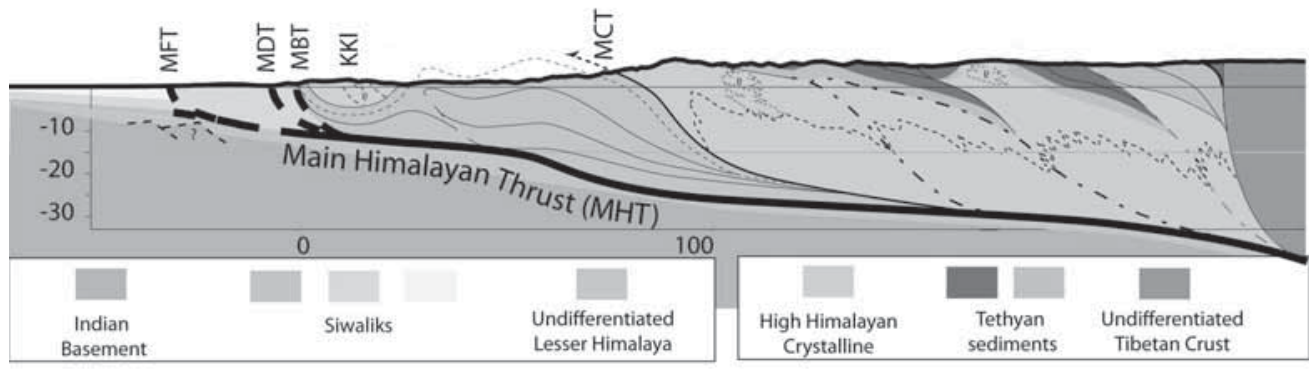

Figure 1. Cross section of the Himalayas along the Kathmandu traverse, showing the main structural units: the Terai plain, south of the Main Frontal Thrust (MFT); the Siwaliks Hills between the MFT and the Main Boundary Thrust (MBT) with in between additional faults, such as the Main Dun Thrust (MDT); the Mahabharat Lekh (Lesser Himalaya) then the Pahar, bounded to the north by the Main Central Thrust (MCT), dominated by the Greater Himalaya (from Bollinger et al., 2004).

The collision occurred at the westernmost edge of India at about 55 million years ago, and thereafter the movement of India was slowed down to a rate of only $5 \mathrm{cma}^{-1}$. In fact, the deformation propagated all over the Asian continent, as expressed by large strike-slip faults, such as those of the Red and Salween rivers, along which most of Central Asia is pushed eastward whereas the western part is blocked by the Pamir knot (Molnar and Tapponnier, 1975). Along and south of the suture zone, the compressional motion between the two plates has been accommodated by slip on a suite of major thrust faults, connected at depth along a major detachment plane, along which most major earthquakes are generated (Seeber and Armbruster, 1981). These major thrust faults (Main Central Thrust, Main Boundary Thrust, Main Dun Thrust, Main Frontal Thrust) delineate an accretionary prism (Fig. 1), and define a series of parallel, asymmetric crest lines, oriented more or less East-West, that become higher towards the north, hence offering, over a limited distance, a succession of contrasted environments. We describe below the different morpho-structural units -both mountain masses and intramontane basins- that typify the Himalayan Range relief.

\subsection{MAJOR HIMALAYAN MORPHO-STRUCTURES}

There is a close relation between the structures and landforms that make up the Himalayas. The Himalayan range is generally subdivided into the following morpho-structural belts: the Terai foothills, the Siwaliks molassic hills, the Lesser Himalaya middle mountains, the Pahar midland basins and valleys, the Greater Himalayan steep and high mountains, the north-Himalayan mountains, and the suture line depression valleys (Fig. 2).

The large alluvial Terai piedmont plain corresponds to the subsiding Himalayan foreland basin. It is formed by the coalescence of mega-fans, built up by the debris carried down by the Indus, Brahmaputra and Ganges rivers and their tributaries; the thickness of debris is maximal in the proximity of the active Main Frontal Thrust.

North of the Terai plain, the first mountain ridges encountered are the Curyia or Siwalik hills (elevation between 300 and $1,000 \mathrm{~m}$ ), made of Mio-Pliocene molasses deformed by thin-skinned tectonics. The deformation is still active to-day, as particularly well expressed by the trellis-like drainage pattern and by the folding, tilting or thrusting of Holocene fluvial terraces, differentiated by their altitude, degree of soil development and ${ }^{14} \mathrm{C}$ dates (Delcaillau, 1992; Lavé and Avouac, 2001). Their ge- 


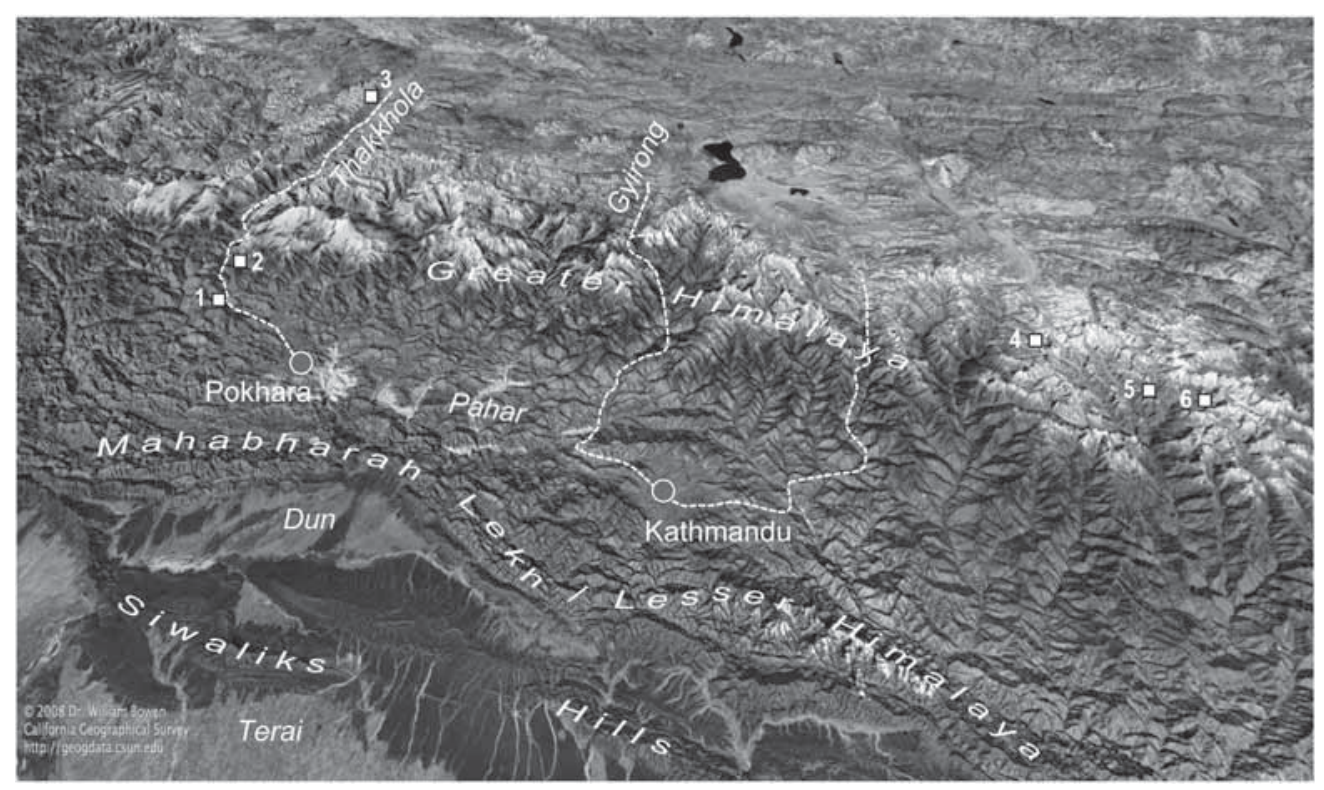

Figure 2. Block diagram of Central Nepal Himalayas with the different morpho-structural belts (mountains and basins) that result from the intra-continental collision. Roads connecting Nepal Midlands to the Tibetan Plateau of China follow up very deep gorges, with a high density of landslide hazard (from East to West: Arniko Highway, Trisuli valley road, Pokhara-Kali Gandaki road).

Numbers refer to localities cited in the text: 1: Benighat; 2: Sikha-Phalate; 3: upper Mustang; 4: Rolpa Tsho (Rolwaling); 5: Dig Tsho; 6: Imja lake (Khumbu Himal) (DEM from W. Bowen 2008; http://geogdata.csun.edu).

ometry, either as stepped strath terraces or cut-and-fill terrace systems, is a response to uplift and warping (frontal ramp) or relative subsidence (piggy-back basins locally called "dun") that typifies the different morphostructural units of a thrust prism (Delcaillau, 1992), connected at depth to the Main Himalayan Thrust, the major detachment plane (Bollinger et al., 2006).

The Mahabharat Lekh suddenly rises from $1,500 \mathrm{~m}$ to close to $3,000 \mathrm{~m}$ : it constitutes the Lesser Himalaya (or Border Range), made up of old material of the Gondwana continent (mainly low-grade Cambrian or older metasediments, i.e. phyllites, quartzites and marbles) thrusting over the Siwaliks molasses (Main Boundary Thrust). Characterized by a fast uplift rate (close to $1 \mathrm{cma}^{-1}$ ), these "Himalayan hills" appear as jagged ridges alternating with narrow valleys, the bayonet pattern of which revealing an adjustment of river inci- sion keeping pace with differential rising of the mountain mass. The Mahabharat Lekh constitutes a remarkable climatic obstacle to the monsoon rains, hence a very unstable geomorphic environment, where landslides, torrent erosion and debris flow scour are the dominant hillslope processes and pose a severe threat to the settlements and main roads corridors linking Nepal to India.

Further to the north, the Pahar appears as a relatively depressed region, where the Midlands inter-mountain basins, such as the Kashmir valley and, in Nepal, the Kathman$\mathrm{du}$ and Pokhara valleys, are aligned discontinuously between the Lesser and Greater Himalayas (Fig. 2). These fairly flat areas are favoured places where paddy fields are abundant and where large cities have developed recently. The Kathmandu and Kashmir valleys are filled with lacustrine sediments rich in fauna, interbedded with lignites that have been dated to the Plio-Pleistocene. 
The $20^{\circ}-25^{\circ}$ northward tilting of the basin fillings along the southern edge of these valleys suggests they are tectonically ponded basins - or piggy-back basins - resulting from the uplift of the Lesser Himalaya thrust unit to the south (Burbank and Johnson, 1983; Delcaillau, 1992).

The midlands valleys abut against the mighty front of the Greater Himalaya that bolsters the highest peaks of the Himalayan Range $(>8,000 \mathrm{~m})$. It corresponds to the 10 $\mathrm{km}$ thick, Main Central Thrust crystalline unit, composed of medium- to high-grade gneisses with leucogranitic intrusions, overtopped by metasedimentary rocks (deposited north of the former Indian passive margin) that uphold the highest Himalayan peaks (Kangchenjunga, Makalu, Everest-Chomolungma, Xixabangma, Manaslu, Annapurna, Dhaulagiri, to name a few) (Gansser, 1964; Colchen et al., 1986). It represents a zone of extreme energy, also characterized by abundant precipitation, with monsoon rainfall exceeding $5 \mathrm{ma}^{-1}$, preceded in spring by convective cloudburst rains, which makes this sector very prone to erosion. Major Himalayan rivers cut across this belt along steep, rocky gorges (Seeber and Gornitz, 1975), with relative relief locally exceeding 6,000 m (e.g., between the glaciated Dhaulagiri $(8,176 \mathrm{~m})$ and Annapurna $(8,091 \mathrm{~m})$ peaks and the Kali Gandaki valley floor, at 2,000 m). In fact, fluvial incision keeps pace with mountain uplift rate (4-8 $\left.\mathrm{mma}^{-1}\right)$; it drives hillslope instabilities and processes, which accomplish most of the denudation work (Fort et al., 2010).

North of the Greater Himalaya, the landscape changes dramatically. The monsoon rains are greatly depleted, giving rise to the dry Himalaya and revealing specific structures like collapsed folded structures of the Tibetan metasedimentary High Himalayan series along the North Himalayan Detachment Fault (Godin, 2003), or the Thakkhola-Mustang graben, that cuts diametrically across the Himalayan structures (Fig. 2). The fill of this graben is composed of two formations (Fort et al., 1982). The lower Tetang Formation, of Miocene age, is related to an early stage of the Himalayan range development and corresponds to a parallel, piggy-back type basin. In contrast, the upper Thakkhola Formation is related to the movement of the Thakkhola normal fault - with its synthetic and still active structures. This basin, together with other north-south oriented grabens developed south of the Tibetan Plateau (e.g., Gyirong), are associated with an east-west extension, made possible by the thickness of the continental crust (nearly 50 $\mathrm{km}$ ) and favoured by the presence of strike slip faults running across the Tibetan Plateau and the adjacent areas (Armijo et al., 1986).

The northernmost limit of the Himalayas corresponds to the ancient suture line between the two Asian and Indian continents, along which the upper Indus and Brahmaputra-Yalung ZangBo rivers are flowing. Along the suture zone, the Tethys oceanic crust and the molasse deposited before the final collision were squeezed, and now outcrop vertically (Valdiya, 1998). The landforms are diversified according to the different palaeogeographic units; in Zanskar (India), the oceanic ophiolitic klippe culminates above $6,000 \mathrm{~m}$, whereas along the Indus valley the contrast is sharp between the south (left) side, made of dissected, deformed molasse, and the north (right) side underlain by the massive Ladakh granodiorites (subduction stage predating the collision).

This succession of the Himalayan morphotectonic units illustrates well what is a continent-continent collisional mountain belt.

\subsection{DENUDATION}

As in any mountains in the world, denudation work in the Himalayas is accomplished by varying processes of different magnitude and frequency (i.e. weathering, landsliding, fluvial activity), animated by both tectonic uplift and climate. Whereas large-scale landslides are very effective in a short time scale, their influence is diluted when considering the rates of mass transport to the sea by large rivers at a longer time scale, with temporary sedimentary traps (intramontane and foreland basins) controlled by morpho-structural units as described above. 


\subsubsection{COLLAPSE STRUCTURES AND LARGE SCALE ROCK FAILURES}

Large, catastrophic slope failures play a prominent role in the denudation history of an active orogen like the Himalayas: they are considered as "formative events" that shape the landscape at a wide range of spatial and time scales (Brunsden and Jones, 1984; Fort and Peulvast, 1995; Hewitt et al., 2008; Korup and Clague, 2009). Such events together with a high uplift rate are crucial to shape and maintain the steepness of the Great Himalayan front (Fort, 1988). They deliver instantaneously a huge volume of debris $(\approx$ cubic kilometre) that is partly and temporarily stored in valleys or intramontane basins (Fig. 3). They also impact valley landforms and evolution (river diversion, valley obstruction, forced sedimentation) that may offset the calculated denudation rates based on bedrock uplift and river incision rates.
In the Western Himalayas and Karakoram, Hewitt (2009) identified hundreds of large rock slide-rock avalanches, most of them being the result of stress release developed in response to earthquake and/or glacial debuttressing. In the Nepal Himalayas, eight giant failures have been recorded to date, with ages varying between pre-Last Glacial advance (30-40 thousand years) and a few hundred years (Fort, 2011). All of them occurred in valleys with steep topography gradient, and several of them are located along distinctive lithological or structural discontinuities (e.g., the North Himalayan Detachment Fault). If some of these landslides are clearly the result of post-glacial gravity instability, other ones are probably earthquake-triggered (Fort, 2000a, 2011). This is the case of the Pokhara valley, located at the foot of the Greater Himalaya near the ramp of the detachment fault, where infrequent, very large

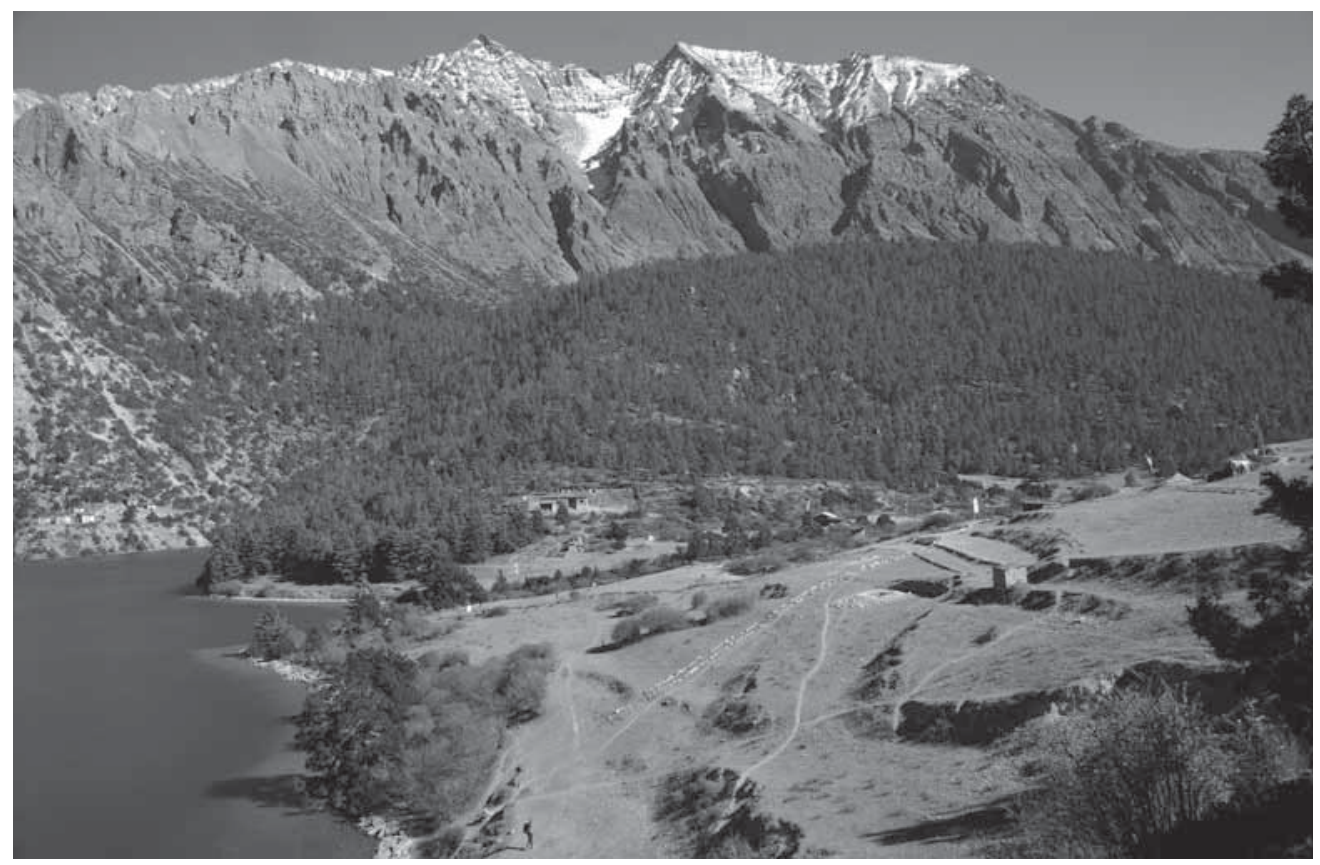

Figure 3. The Phoksundo lake (Dolpo District) viewed from the Northwest. The lake was formed by a large-scale rock-avalanche of about 1.5 billion $\mathrm{m}^{3}$ in volume

The photo shows the lake (elevation of $3,600 \mathrm{~m}$, area of about 4.5 to $5 \mathrm{~km}^{2}$ ), the landslide dam (under the forest cover, and Ringmo fields), and the source area (background), a 5,148 m high cliff made of Cambro-Ordovician shaly limestones. (๑ M. Fort, 2010) 
seismic ruptures are taking place (Fig. 4). This valley was impacted by a giant rock avalanche generated south of the Annapurna IV Peak $(7,855 \mathrm{~m})$, most probably triggered by the major 1505 (AD) earthquake, according to ${ }^{14} \mathrm{C}$ dates (Fort, 1987, 2010). The valley has been filled by a 4 cubic-kilometre debris flow that buried the former topography. The impacts of this event are still visible on the present landscape, such as remnants of lakes dammed by the debris flow (Phewa, Begnas, Rupa Tals) at the mouth of tributary valleys, or the dramatic set of unpaired terraces incised throughout the 60 -to- $100 \mathrm{~m}$ thick debris flow material by the Seti River still adjusting its longitudinal profile (incision rate of $20 \mathrm{cma}^{-1}$ ). This rock avalanche event corresponds, for the upper Seti catchment, to a sediment yield of $22,860 \mathrm{~m}^{3} \mathrm{a}^{-1} \mathrm{~km}^{-2}$, a figure among the highest given for the Himalayan catchments (Fort, 1987; Fort and
Peulvast, 1995). However, even though the geomorphic work accomplished by such an event is important, the denudation rates are limited because it involves mostly redistribution rather than net erosion (see below). The Pokhara event also demonstrates that, despite their low frequency, such large slope failure potentially represent a major threat for densely inhabited areas (Pokhara population is approximately 250,000$)$, as was recently demonstrated by the 2010 Attabad event that affected thousands of people in the Hunza valley (Pakistan).

\subsubsection{CLIMATE-TECTONICS INTERACTION FORCING}

Studies on coupling between tectonics, climate, and erosion (Molnar and England, 1990; Avouac and Burov, 1996; Willett, 1999) have emphasized the key role of erosional processes and their efficiency in shap-

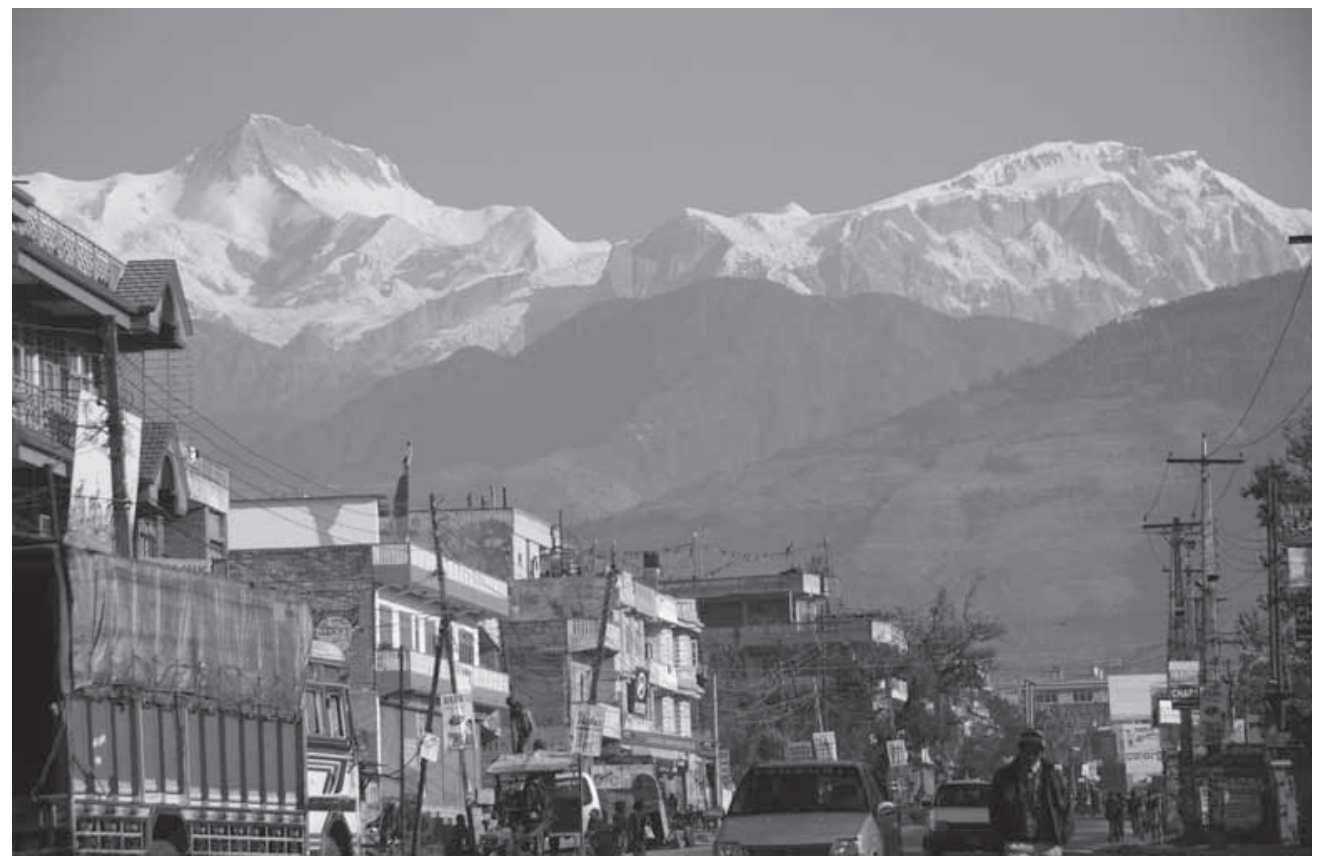

Figure 4. The development of Pokhara city (800 m a.s.l.; $>250,000$ hab.) during the last three decades has increased the permanent threat represented by the glaciated peaks and overhanging cliffs of the Annapurna Range (Annapurna II Peak 7,937 m and Lamjung Himal 6,983 m), one of the most dramatic scenery of the Greater Himalaya; the steep mountain wall corresponds to the front of the Main Central Thrust unit, subject to low frequency, high magnitude rock failures. (C) M. Fort, 2009) 
ing and uplifting mountain ranges. A variable monsoonal climate is indeed an integral part of the present Himalayan denudation system, acting as an erosion trigger of variable efficiency depending on which segment of the 2,500 km long Himalayan range is considered. Erosion indirectly fosters isostatic rebound and uplift, the uplift being continuously sustained by the subduction of the Indian plate beneath Asia. In the absence of limits due to rock strength, monsoon rains do control most of slope instabilities (via the pore pressure and the chemical weathering rate), hence, hillslope angle and relief, which decrease when mean annual rainfall increase (Gabet et al., 2004). Another influence of monsoon climate on Himalayan erosion is its role on the long-term ocean-atmosphere budget of carbon dioxide: whereas metamorphic decarbonation releases $\mathrm{CO}_{2}$, rapid silicate weathering of the uplifted Himalayan range causes a fall in atmospheric $\mathrm{CO}_{2}$ levels, hence possibly climate cooling (Raymo and Ruddiman, 1992); in addition the burial of organic carbon in sedimentary reservoirs contribute to carbon sequestration in continental and oceanic sinks (France-Lanord and Derry, 1997). All elements of the erosional Himalayan system -uplift and subsidence, isostatic readjustments, monsoon climate, chemical cycles are thus interdependent (Fig. 5), with a positive feedback relationship between focused erosion and deformation at the front of the Higher Himalaya range (Hodges et al., 2004) that command the zones where erosion and aggradation are taking place.

The large Himalayan rivers (Ganges, Indus and Brahmaputra) have, for millions of years, collected the debris produced by the erosion of the Himalayan range, debris that either accumulates in the foreland trough or

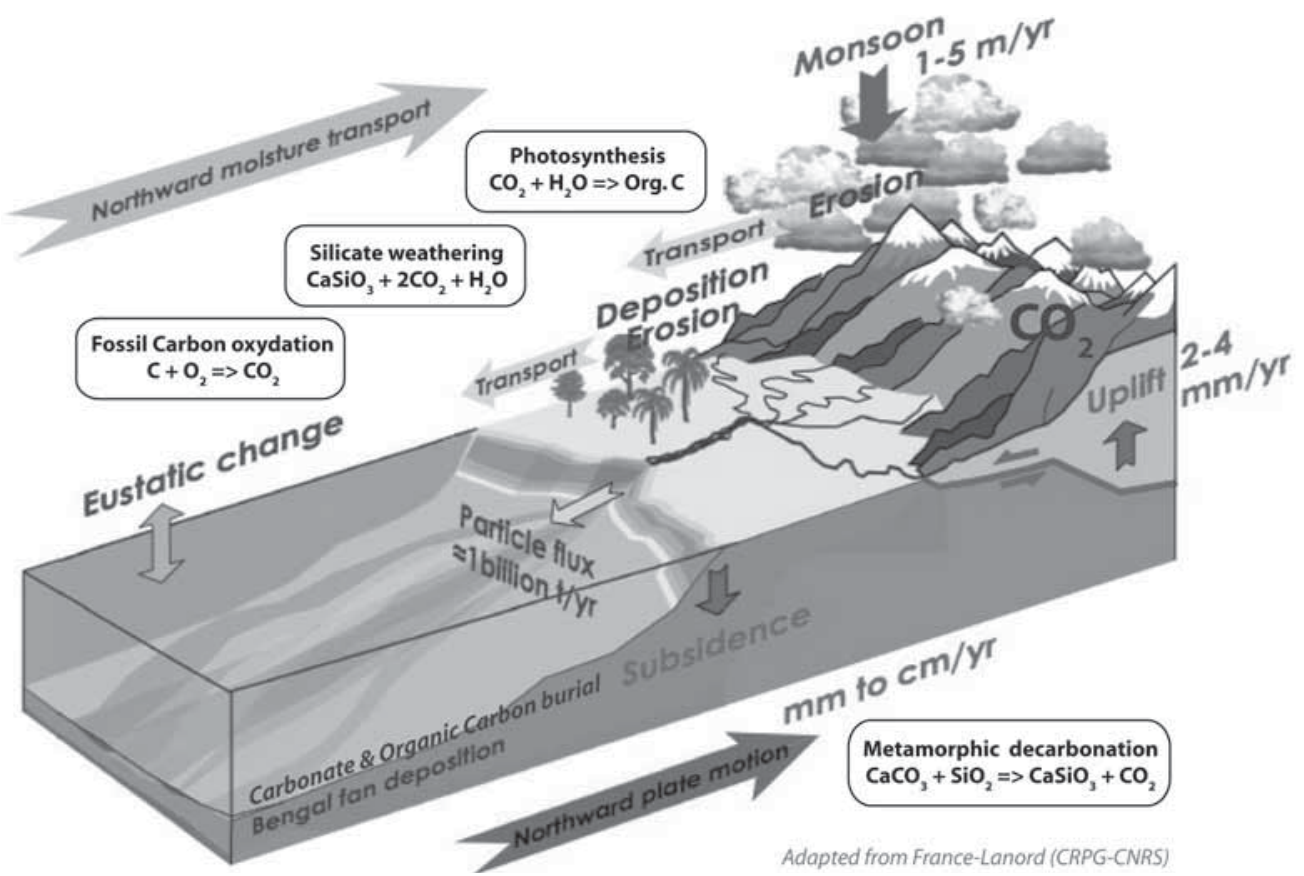

Figure 5. The Himalayan mountain system: a balance between rock uplift controlled by plate tectonic, and erosion (landslides and fluvial incision) mostly controlled by climate; monsoon rainfall also controls carbon cycle in both atmospheric and oceanic reservoirs (metamorphic decarbonation and fossil carbon oxidation $v s$ silicate weathering). Adapted after France-Lanord, CNRS-CRPG

(Nancy, France). 
is conveyed in suspension down to the Bengal and Indus submarine fans. The particle flux emerging from the mountains is estimated to be of the order of 1 billion tons per year by Métivier et al. (1999), who calculated that $1 \times 10^{6} \pm 3 \times 10^{5} \mathrm{~km}^{3}$ of sediments were eroded away from the Himalayas and deposited in the Gangetic plain and Bengal fan during the last 2 Myrs.

\section{GEOMORPHIC PROCESSES AND HAZARDS IN A DEVELOPING COUNTRY}

Landslides represent the most frequent hazards in tropical mountain environments. In the narrow Himalayan valleys, the strong hillslope-channel coupling favours the occurrence of landslide dams and resulting floods, with impacts on land and people (Fort et al., 2010). In a developing country such as Nepal, they represent a major threat, all the more damaging that this country is fully involved in developing its network of rural roads, a process that may indirectly increase death toll and economic losses (Petley et al., 2007). We present a few pieces of evidence of an increasing landslide risk in relation to increasing vulnerability of people and assets.

\subsection{IS THERE A MAN-INDUCED HIMALAYAN ENVIRONMENT DEGRADATION?}

Himalayan uplands are densely populated and cultivated, as shown by the many terraced-fields that entirely cover mountain slopes (Fig. 6). In the late 1970's, some alarmist scientists considered Himalayan erosion (chiefly gullies and landslides) as being mostly the result of mismanagement of mountain slopes by human communities (Ekholm, 1976), in a theory called the "Himalayan Environment Degradation". It was argued that, locally, deforestation exposes the soils to aggressive pluvial action, causing more erosion and so reducing crop yields; this often gives rise to further deforestation as communities are driven to compensate for loss of soil by further enlarging the cultivated areas. Regionally, this positive feedback can give rise to both water deficit problems and more damaging floods, often choking irrigation reservoirs with the eroded sediments and sometimes leading to excess concentration of fertilizers. However, the reality is much more complex (see the debate and arguments in Ives and Messerli, 1989). We cannot deny that, locally, some signs of land degradation can be observed, such as lopped trees, superficial soil erosion, or relict trees on recently cleared and cultivated hillslopes. Yet, when observations are made to some distance from the main roads, it appears that in most valleys, hillslope management practices are fairly sustainable, although they do require a large labour input from the farmers.

\subsection{LANDSLIDING, A NATURAL AND DOMINANT PROCESS IMPACTING VALLEY BOTTOMS}

The reality is that hillslope erosion and, more specifically, landsliding is a natural and dominant process in the Himalayas (Brunsden et al., 1981; Gerrard, 1994; Starkel and Subhashranjan, 2000). Triggering factors are mostly rains (more than $90 \%$ landslides are rainfall triggered), and to some extent earthquakes, whilst bedrock lithology (debris soils vs rocky slopes), slope gradient, form and aspect appear as main control factors. Whereas potential superficial soil erosion (gullying) is at its maximum at the end of the dry season with the onset of intense convective storm rains (Carson, 1985), most of the landslides do occur during the monsoon, more specifically at the end of the monsoon season when the soils and bedrock are saturated (Carson, 1985; Gabet et al., 2004). Rainfall thresholds susceptible to trigger landslide vary according to authors and areas: in the Nepal Himalayas, daily rainfall range from $100 \mathrm{~mm}$ (Caine and Mool, 1982) to $260 \mathrm{~mm}$ (Dahal et al., 2006); in the Darjeeling Himalayas, Starkel $(1972,1976)$ and Froehlich and Starkel (1987) give a threshold of $250 \mathrm{~mm} / 24 \mathrm{~h}$ or three-day rainfall of $>350 \mathrm{~mm}$ to trigger landslide. Dahal and Hasegawa (2008) suggest that landslides might initiate when the daily precipitation exceeds $144 \mathrm{~mm}$, also 


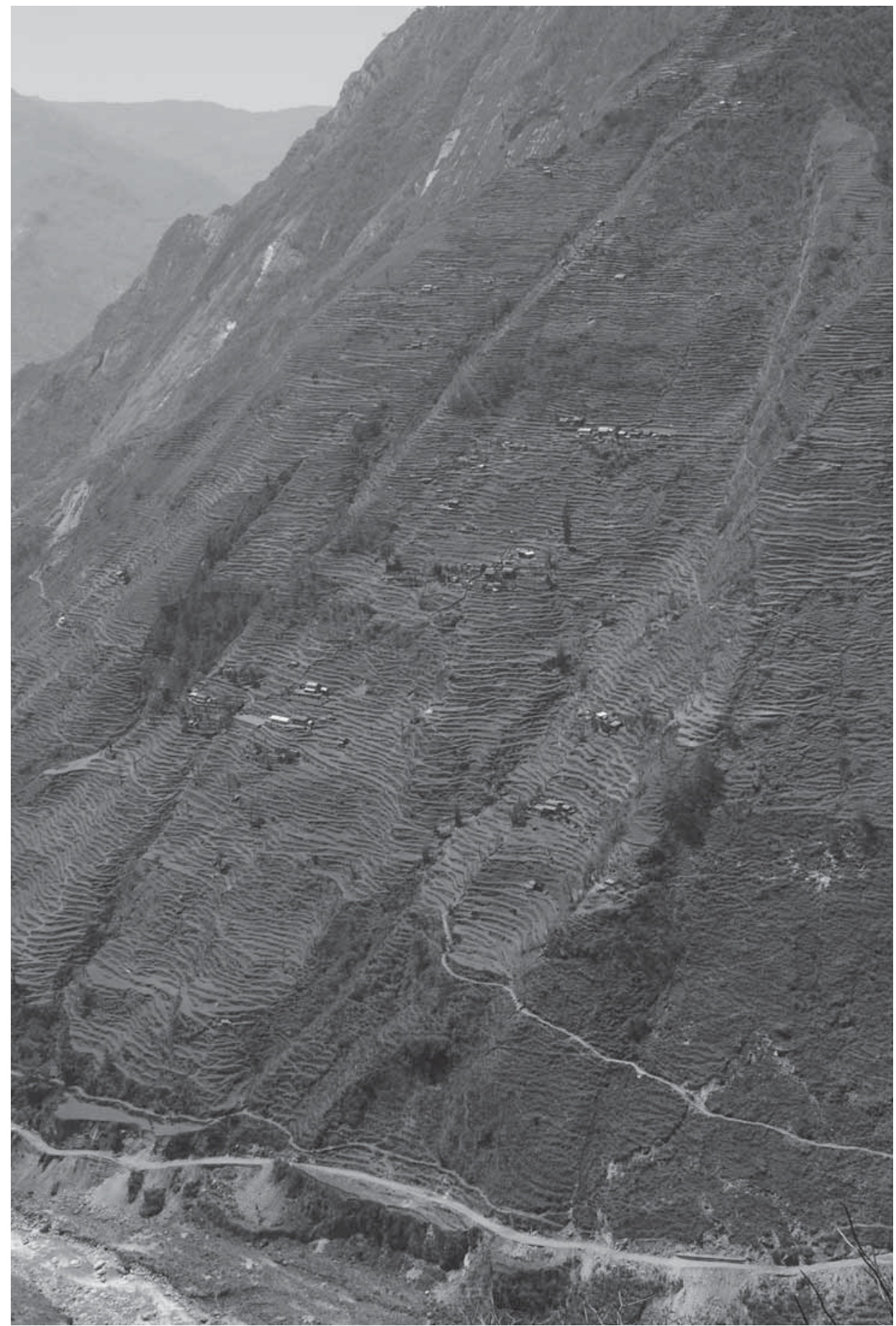

Figure 6. Terraced fields on a steep debris slope, middle Kali Gandaki valley (1,200 m, Myagdi District). The new road is cut into the instable foot slope. (@ M. Fort, 2009) 

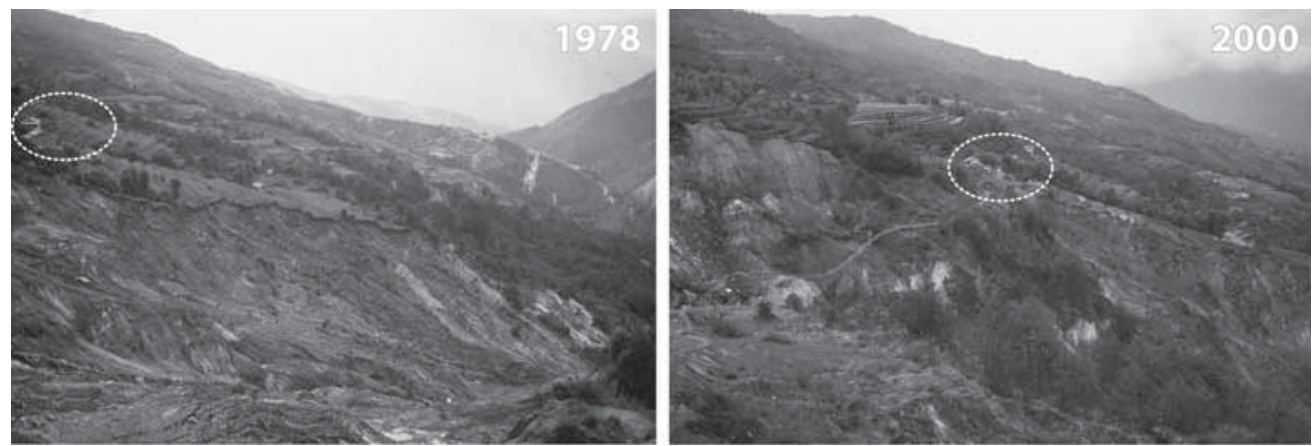

Figure 7. Sikha-Phalate hillslope (2,000 m, Myagdi District), evolution between 1978 and 2000, with a group of houses as landmark. Control factors are bedrock lithology (alternating chlorite-schists and white quartzites of the Lesser Himalayas), structure (dip slope) and north oriented slope. The landslide, active during monsoon rainfall, has expanded laterally and upslope during the last two decades. In 2000, temporary stabilization is observed, favoured by revegetating with Alnus nepalensis (foreground) by the villagers. Note the foot trail crossing the landslide. (ㄷ M. Fort)

pointing out the critical role of antecedent rainfall in soils saturation and ground water level. Clearly, the vegetation cover has little impact on landslide development; indeed most landslides affect depths that very often largely exceed those of the tree-roots, and they generally develop and expand rapidly, as clearly shown between Shika and Phalate (Fig. 7; see Fig. 2, site 2).

In fact, medium-scale, larger frequency landslides appear as a threat that may impact not only the forested (or not) mountain slopes, but also river valley bottoms. More specifically, landslide hazard is particularly acute across the Greater Himalayas, where the confinement of valleys favours landslide interaction with rivers. Many examples of Himalayan river valleys blocked by landslides, rock falls, or alluvial fans, have been reported (Brunsden et al., 1981; Weidinger and Ibetsberger, 2000; Paul et al., 2000; Naithani, 2001; Dunning et al., 2006; Fort et al., 2010). These river blockages, lasting between a few hours to a few weeks, may result in temporary landslide dammed lakes, with backwater inundation. The stability of the landslide dam is crucial, and is controlled by the material and volume of the dam, and topographic context. From these factors depend the duration of the landslide dam and the possibility of outburst flooding generated by dam overtopping or failure. When it occurs, outburst flooding may cause secondary landslides down valley, hence potential new blockages and more floods. Due to the topographic constraints, landslide outburst floods may consequently result in a large number of fatalities and losses in property. As a whole, landslides are thus considered as negative features reflecting the "fragility" of the Himalayas and appearing very harmful to the Himalayan populations.

\subsection{LANDSLIDES AND INFRASTRUCTURE DEVELOPMENT}

This statement cannot be denied, but should be discussed in the light of settlement patterns and their recent changes, particularly in relation to road building and subsequent economic development and urbanisation.

In Nepal Himalayas, where agriculture remains the main economic activity in mountain areas, village fields are traditionally and most often located along hill slopes, upon "old" landslide material. Despite hazards and induced risks generated by landslides, such locations are positively valued as they provide good opportunities for terracing and farming (gentler slopes, heterogeneous loose debris including soft and fine 


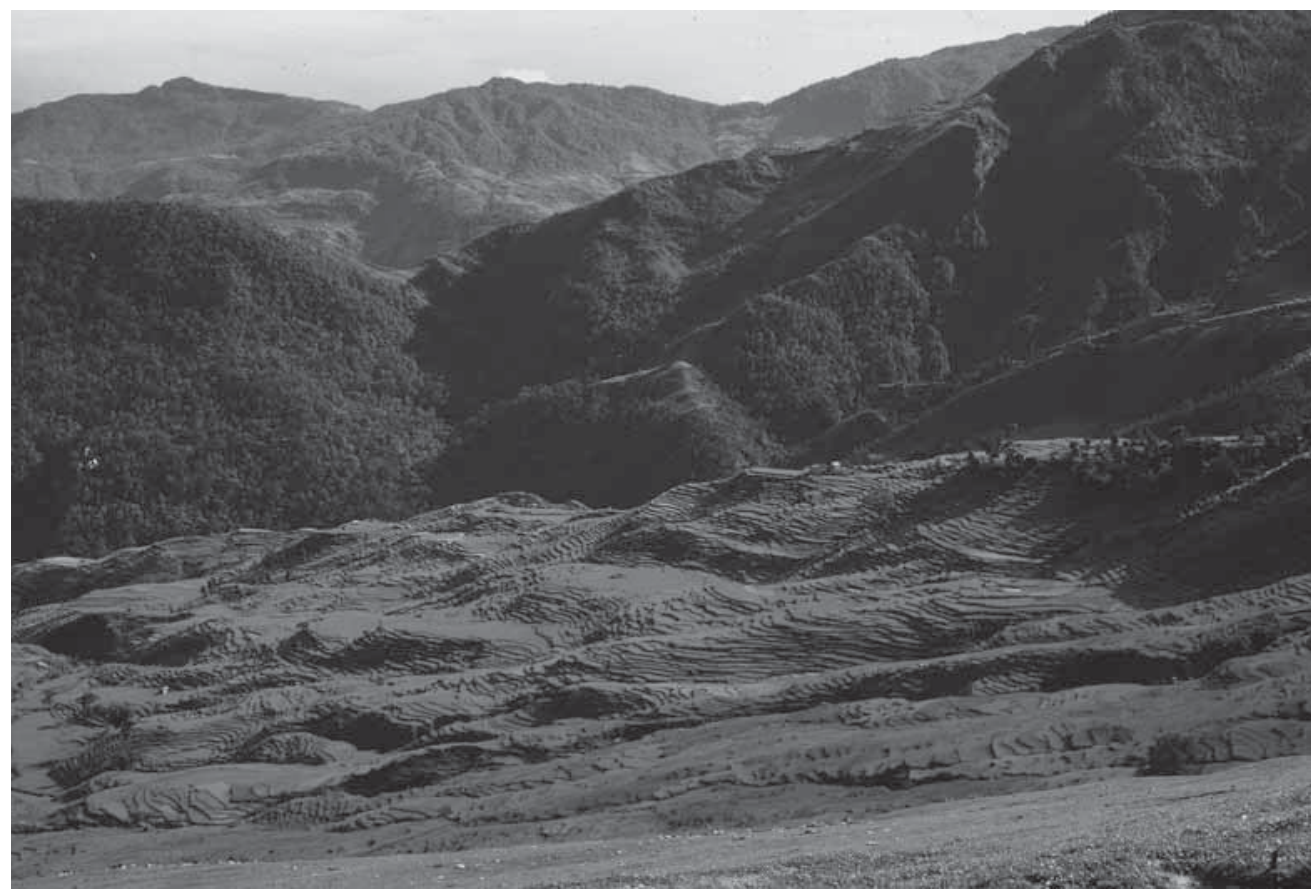

Figure 8. Irrigated rice fields on slumped shaly bedrock (1,500 m, Harpan khola catchment, Kaski District, West of Pokhara). (ㅇ M. Fort, 1978)

soils, chemical regeneration, water springs) (Fig. 8) and house building (quarrying of the largest blocks embedded in the colluvium). In addition, their elevation $(\approx 2,000 \mathrm{~m})$ corresponds to the tropical-temperate (malaria free) transitional biotic belt, whereas their location at mid-slope, below rocky spurs and above deeply entrenched river thalwegs, also favoured the optimization of the design of old foot-trails linking villages to other settlements in adjacent valleys. An active landslide was never a major obstacle to traditional societies developed before modern road infrastructures (Fig. 7): people could always walk across unstable landslide masses, with villagers readjusting and repairing the foot trails on the basis of community labour.

Conversely, the economic development of the last two decades and the construction of new roads are often considered as the causes of an upward trend in small landslide occurrences, regardless of the geomorphic setting and "natural" causes of landslides. Is the presence of a road the cause of these active processes, as often pointed out (Petley et al., 2007)? Or does the road represent an additional, costly and more vulnerable asset compared to traditional foot trails?

Generally, the population perceive the construction of a new road in a very positive way: it improves accessibility to the market, hence favours exchange of goods and services with neighbouring valleys and countries. Locally, it results in rural development (production of specific agricultural resources such as organic crops, medical plants, fruits) and booming urbanization, located in sites more exposed to natural hazards (e.g., along the narrow fluvial terrace strips) than formerly. Yet a road also favours out-migration of young people in search of better education and jobs that in turn may cause a progressive abandonment of resource management activities and landslide mitigation systems in the rural areas (Khanal and Watanabe, 2006). 
In fact, all these recent processes, such as infrastructure development and associated land-use changes spread spatially without consideration of the potential dangers that may result from landslides and floods hazards. Clearly, there is an increasing level and changing nature of vulnerability, all the more important that geomorphic hazards affect the major arteries that traverse the entire Himalayan range (Fig. 2): the "old" Arniko road, joining Kathmandu to Lhasa, and the two new roads along the Trisuli khola and Kali Gandaki valleys respectively, already open to traffic despite the fact they are not fully completed (late 2010).

A good example of increasing risk with time is provided by the Benighat case (Myagdi District; see Fig. 2, site 1), where the new Kali Gandaki road has been designed along the left bank of the valley, at the foot of a mountain slope prone to large-scale mass wasting (Fig. 9). Some 30 years ago, a large earth flow occurred that shortly dammed the Kali Gandaki River downstream of its confluence with the Mayangdi River. At that time, Benighat was still a small market (bazaar) place. In 2007, the same hillslope appeared to be at least temporarily stabilized, with the regeneration of tree cover (Alnus nep.) encouraged by village communities. However, the dangerous slope is still there, with the recent construction of the road cut at its foot. Meanwhile, Benighat has become a large city because of the many facilities made available by the presence of the road; there is now a considerable number of people and assets at risks under the threat of this dormant landslide they are not
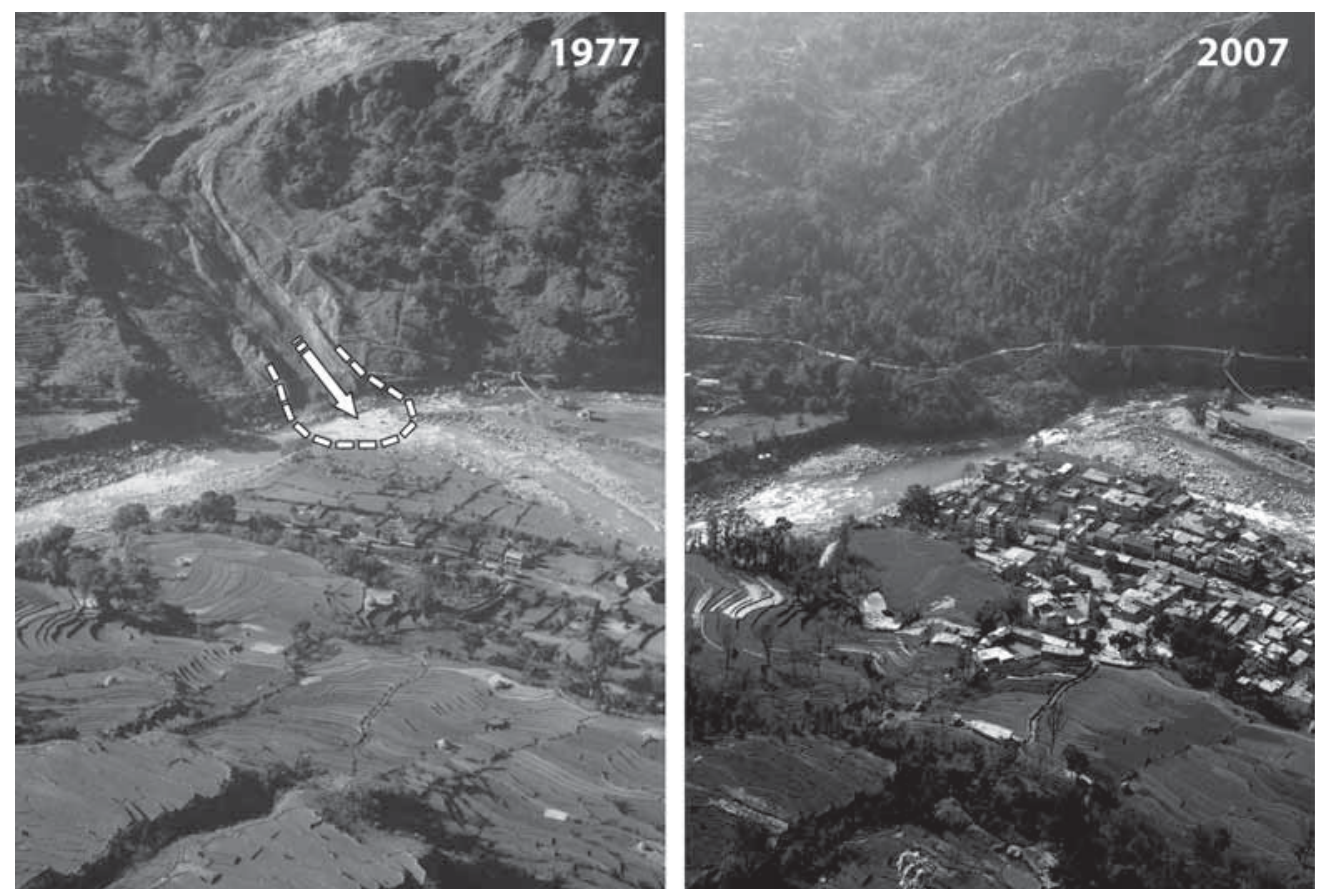

Figure 9. 30-year slope evolution near Benighat (Myagdi District). The chlorite-schist lithology favours the recurrent development of earth flow, as attested by the series of older, longitudinal levees on both side of the active flow (1977). Conservation measures (planting of alders, Alnus nepalensis) are quite efficient in controlling temporarily the earthflow as observed in 2007. Yet the persistent instability of the entire mountain slope and the likelihood of a river blockage endangers the Benighat city, recently developed in response to the construction of the road. (C) M. Fort) 
aware of. Direct risks along the road (destruction of the road alignment, losses and injuries to travellers, damages to vehicles) and adjacent urbanised areas (inundation by backwater flooding), and indirect risks such as day-to-week-long closures may eventually cause heavy economic loss and a growing number of affected people. Similarly, there are many other known sites of recurrent landslides and related damages along this Kali Gandaki road (Fort et al., 2010) and other national highways, e.g., Kathmandu-Pokhara-Narayanghat Highway; Kathmandu-Kodari-Chinese border Arniko Highway (Adikhari and Koshimizu, 2005; Bhandary et al., 2008; Oven et al., 2008). Mitigation measures such as slope monitoring and early warning systems, together with information of the local population on potential disasters should be encouraged. Yet, making these roads safer would require a massive maintenance budget that Nepal probably cannot afford.

Finally, one can acknowledge the expansion of road network in Nepal as a good way to open landlocked Himalayan valleys and favour exchange of goods between complementary environments (tropical South Asia vs continental Central Asia). Conversely, in this landslide prone environment, it reinforces the functional vulnerability that may arise from any traffic interruption along these highly strategic and trading link roads between China and Nepal. Indirect economic drawbacks may additionally come from disappointed tourism and resulting disuse of classical trekking routes (Annapurna tour, Langtang National Park, etc.). Eventually, any aggravation of natural hazards due to climate change (i.e. monsoon strengthening) also questions the maintenance of such roads for the next decades.

\section{FUTURE CHANGE}

There are some important issues concerning future for the younger generations. Economic development may be jeopardized by Himalayan environment, with its constraints and hazards (earthquakes, floods, access to water resource), to be considered in a context of global warming.

\subsection{EARTHQUAKE THREAT}

The Himalayan range may be affected by severe earthquakes as attested by historical seismicity records (Nakata, 1972; Bilham and Wallace, 2005). The impact of the 2005 earthquake that affected Kashmir in October 2005 gives an idea of the amount of loss and damage to be expected when the next large earthquake occurs in the Himalayan region. The seismicity map of Nepal (Fig. 10) shows clearly which areas of the Himalayan range are likely to be the next to be affected: the central and western part of $\mathrm{Ne}$ pal along the Himalayan front where stress accumulation rate is the highest. As mentioned earlier, earthquakes are generated along the Main Himalayan Thrust (Fig. 1), whereas north of the Greater Himalaya most of the shortening is accommodated continuously along a creeping zone, south of the Greater Himalaya, where most of the population lives (under 3,500 m elevation). The detachment zone is generally locked, so that the energy of the convergence accumulates until it is suddenly released (Bollinger et al., 2004b); the longer the lock, the greater the earthquake and the resultant damage.

Kathmandu city lies within this zone, and is ranked as the most earthquake vulnerable city in the world (Bilham and Wallace, 2005). Indeed, the city was badly affected by the Bihar earthquake in 1934 (magnitude 8.1, Richter scale), all the more damaging that the Kathmandu valley is built on soft Pleistocene, lacustrine substrate; more than 8,500 people were killed. The rapid development of the city during the past 25 years (increase by $6.5 \%$ every year, representing more than 2.5 million people living in the valley), the poor quality of the buildings and unplanned urbanization, the unpreparedness of the population and their little awareness of the dangers, the limited access to medical facilities, and the poor expertise and resource for emergency and rescue operations collectively make the Kathmandu valley one of the most 


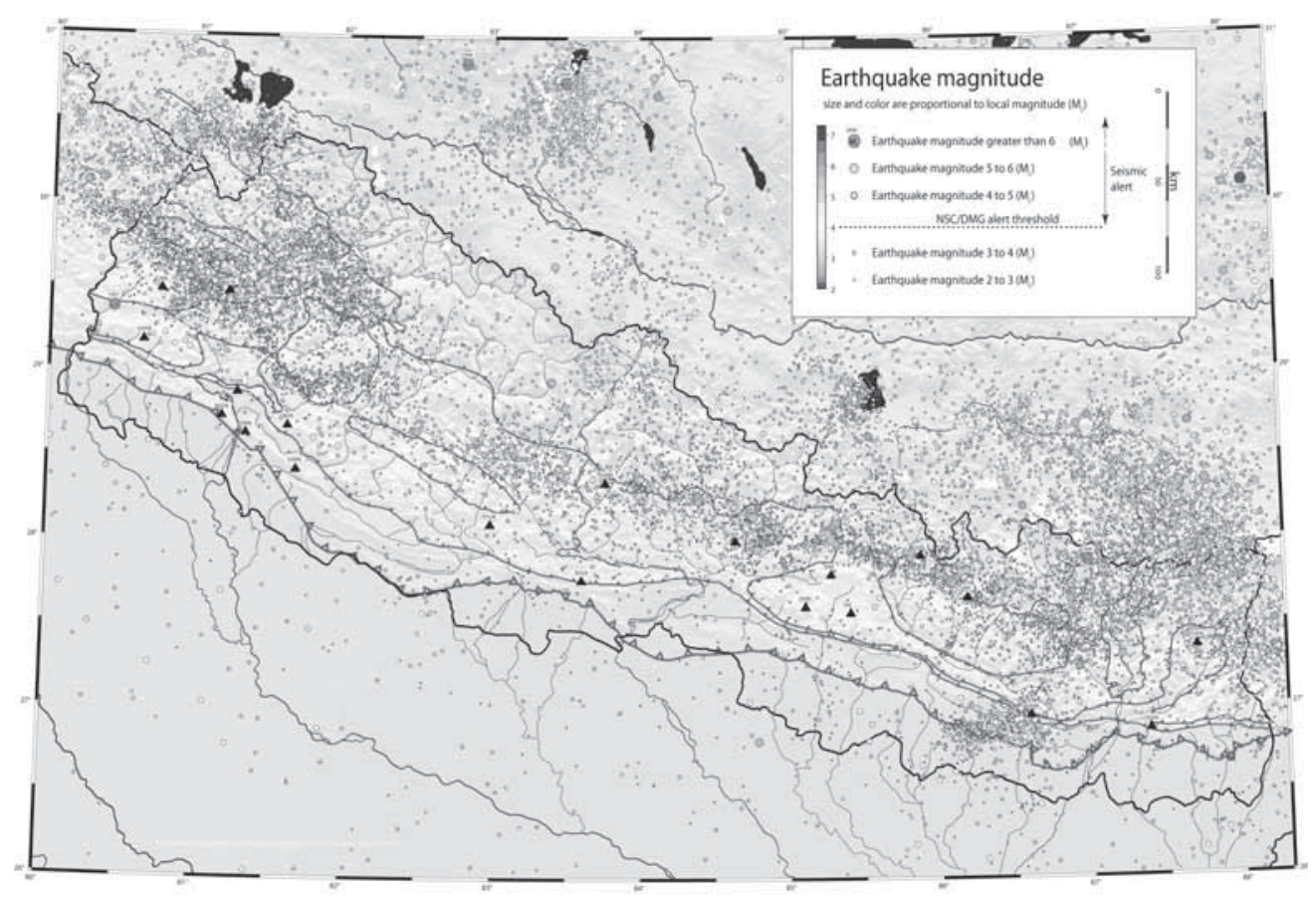

Figure 10. Earthquake magnitude map of Nepal Himalayas (1:1,000,000, NSC4) compiled for the period 1994-2005 by the National Seismological Centre of Nepal, Department of Mines and Geology

(Kathmandu). The map shows clearly the importance of microseismicity and the concentration of large portion of earthquakes $(M>5)$ along a belt following the front of the Greater Himalayas (focal mechanisms associated with the MHT ramp and thrusting perpendicular to the range).

vulnerable sites for the next major earthquake. Actually, an earthquake on the range of 8 in the Richter scale is due anytime, and would cause significantly greater human casualties, physical damages and economic loss than in 1934. A survey by KVERMP (Kathmandu Valley Earthquake Risk Management Project) in 2003/2004 warned that up to 5 percent of the valley's population could be killed and up to 25 percent severely injured; in addition, about 95 percent of water supply pipes might explode and 50 percent of bridges and 10 percent of roads could collapse in the valley, hence making hospitals and most of the public services non-operational. Nepal, one of the poorest countries in the world, would obviously not be able to deal with such a large-scale disaster without international assistance, even though every year the "Earthquake Safety Day" is aimed at disaster risk reduction, in raising public awareness and calling for community initiative and adherence to the building code in order to minimise the damages caused by a seismic event.

\subsection{IMPACTS OF CLIMATE CHANGE}

The second type of threats that may affect the Himalayas and the surrounding areas is related to Climate Change, which is expected to have a major impact on hydrological cycle and water resource, and on natural hazards.

\subsubsection{GLACIERS: A WATER RESOURCE?}

The Himalayan glaciers cover a total area of about 35,000 square kilometres; they contain a volume of 3,734 cubic kilometres of 
ice, and provide about 500 cubic kilometres of water annually. About two third of them are receding, at a rate faster than the world average (Dyurgerov and Meier, 2005), a fact interpreted as resulting from precipitation decrease in combination with temperature increase, such that glacier shrinkage might accelerate if climatic warming and drying continue. However, this drying has been recently challenged, and a number of recent studies suggest the reality might be more complex.

Alford and Armstrong (2010) estimate that the contribution of glacier annual melt water to annual stream flow into the Ganges Basin from the glacierized catchments of the Nepal Himalayas represents approximately $4 \%$ of the total annual stream flow volume of the rivers of Nepal, and thus, is a minor component of the annual flow of the Ganges River. These authors conclude that neither stream flow timing nor volume of the rivers flowing into the Ganges Basin from Nepal will be affected materially by a continued retreat of the glaciers of the Nepal Himalayas. In fact, Nepal glaciers are of summer accumulation type that controls their seasonal runoff signal and the distribution of mass balance with elevation (Thayyen and Gergen, 2010). Having their main accumulation season and ablation season during the summer monsoon, their contribution to runoff is not that large in many river basins when averaged for the entire year, but does become seasonally important. According to the same authors, the glacier component in the stream discharge is highest during the years of low summer runoff (i.e. relatively low monsoon rainfall). Therefore, the importance of glaciers cannot be assessed without an examination of the seasonal impact of glaciers on river flow (Kulkarni et al., 2010). In the absence of a dense network of climate and gauge stations, various snowmelt models based on satellite-derived snow cover suggest that there will be a $30-50 \%$ reduction in dry season flow with large along-strike variations (Bookhagen and Burbank, 2010). Yet the models do not account for the complexity of mountain environments resulting from the effects of slope, elevation, and orientation of mountain ridges. More specifically in the $\mathrm{Ne}$ pal Himalayas, the wet, monsoon dominated downstream climates and runoff will not much affect the river discharge, hence, water availability and food security in contrast to what has been suggested in the Indus and Brahmaputra basins (Immerzeel et al., 2010).

\subsubsection{HAZARDS INDUCED BY GLACIAL RETREAT: GLOFS}

Projected global warming will cause most Himalayan glaciers to continue to retreat and thin, even though a few examples of advancing glaciers are known in the Karakoram (Hewitt, 2005). One major concern is, with glacier retreat, the dramatic development of meltwater lakes behind loosely consolidated Little Ice Age end moraines. With the warming trend observed from the 1980's, there is an increasing likelihood of catastrophic glacial lake outburst floods (GLOFs) that might cause heavy losses of life and property in the high valleys. Among the 24 GLOFs known events recorded in Nepal, some of them were particularly serious, such as in the Bhote Kosi (1964) and the Sun Kosi valleys (1981). Yet the Dig Tsho GLOF (Fig. 2, site 5) that occurred in 1985 in the Khumbu area (Vuichard and Zimmermann, 1987) is considered as the founding event that raised concern about GLOFs hazards. Indeed, this event was very damaging, destroying the nearly completed Namche Small Hydel Project, many bridges and washing away cattle as far as $60 \mathrm{~km}$ down valley of the Dudh Kosi: about 6-to-10 million cubic metres of water and about 3 million cubic metres of debris were released, and the discharge (two orders of magnitude higher than the average) resulted in both erosion and aggradation that propagated along more than one hundred kilometres downstream (Vuichard and Zimmerman, 1987; Cenderelli and Wohl, 2003). This outbreak flood caused more than three million dollars worth of damage and disrupted the downstream community of Khumbu Sherpas for several months (ICIMOD 2011).

More than two thousand moraine-dammed lakes have developed in the past 
40 years in the Nepal Himalayas (Mool et al., 2001), out of which about 20 are considered as potentially dangerous. Some moraine-dammed lakes may also develop in very dry areas such as the Mustang District (Thakkhola graben, Fig. 2, site 3), where a GLOF event occurred in 1988 and destroyed many houses and fields, also ruining high pasture meadows (Fig. 11; Fort, $2000 \mathrm{~b})$. More generally, because of the presence of settlements downstream, most of these lakes (like the Rolpa Tsho in the Rolwaling valley; location in Fig. 2, site 4) are now carefully monitored using satellite images (mostly surveying the lake area expansion rather than lake volume), that may result in mitigation measures such as partial draining of the threatening lake, as was done in Rolwaling Himal in the late 1990's. A crucial issue is the stability of these morainic dams as assessed by different criteria: dissection of the moraine by local drainage, potential seepage occurrence, lake water level rise, behaviour of dead ice, instability of the slopes and hanging glaciers overlooking the lake that might triggered a surge wave, etc.

In the Everest-Khumbu Himal zone, the Imja lake (Fig. 2, site 6) is particularly closely studied because of its accessibility and touristic importance (Bajracharaja and Mool, 2009); it also represents a good study case of balancing between the quite frequent alarmist attitude of mass media and the uncertainty derived by careful scientific expertises. In a recent study, Watanabe et al. (2009) tried to assess characteristics of the lake growth over the last 50 years, and to evaluate the degree of danger of catastrophic drainage. On the basis of repeated intensive field surveys and detailed satellite images analysis,

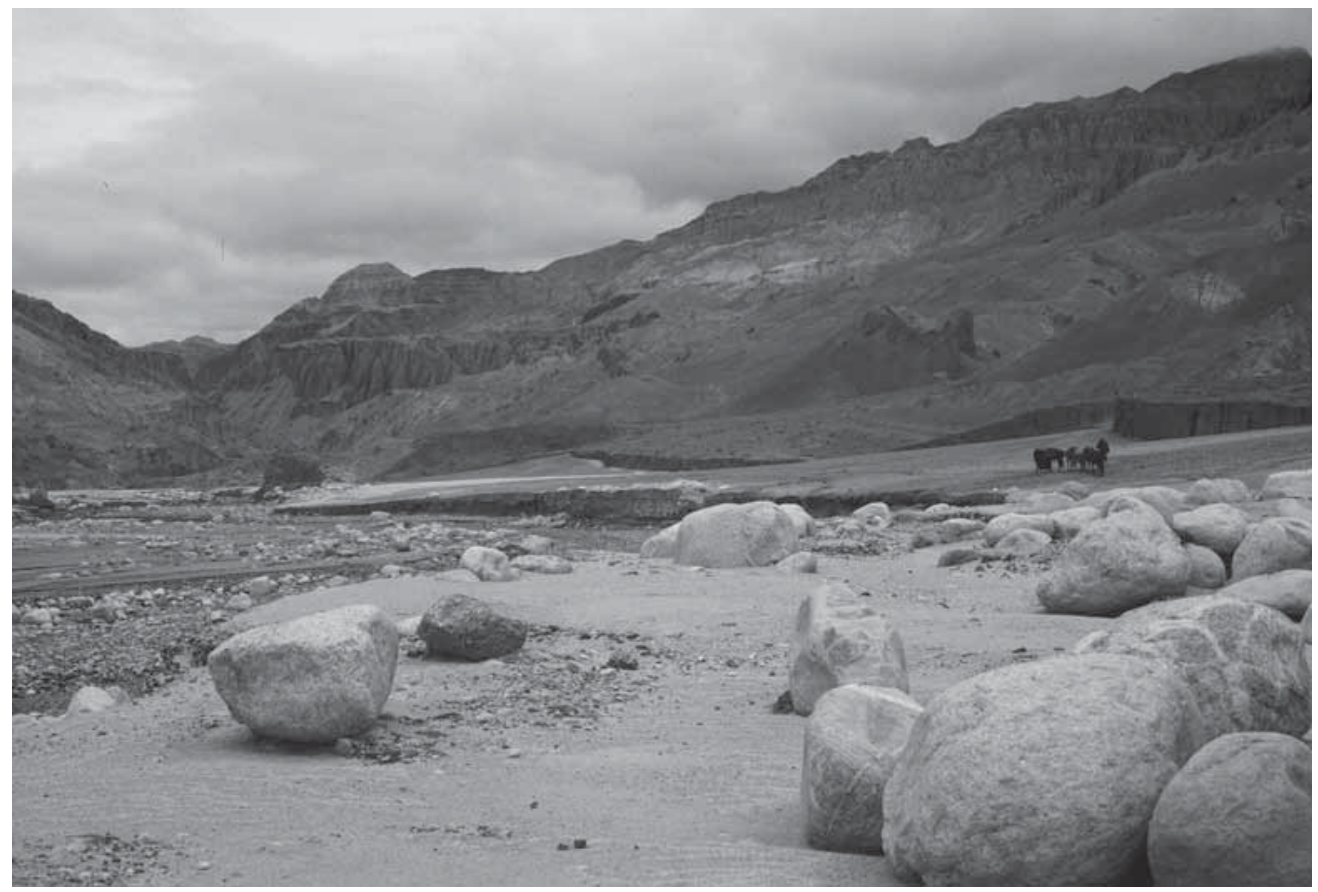

Figure 11. Evidence of a catastrophic Glacial Lake Outburst flood that occurred in 1988; it originated in the glaciated Main Shail Range (6,235 m) bounding the Thakkhola-Mustang basin to the west (see

Fig. 1 for general location). Metric granitic boulders were carried downvalley by a dense debris flow for more than $30 \mathrm{~km}$ in distance and spread over the present upper Kali Gandaki thalweg and terraces.

(C) M. Fort, 1993) 
these authors conclude that the Imja lake is not as immediately dangerous as formerly said. The lake area expansion does not pose a threat of frontal moraine breaching; conversely the up-glacier expansion, hence possible higher ice-cliff would recommend modelling the height of a possible impulsed wave; therefore, careful surveys of the evolution of both morphology of the morainic dam and surrounding slopes, together with monitoring of the lake parameters, are to be systemically developed (Watanabe et al., 2009; ICIMOD 2011).

More general actions are now undertaken to collect information at Hindu-Kush-Himalayan scale, and elaborate a coordinated approach in updating data (field surveys, satellite monitoring), mitigation actions and increasing public awareness, collectively all the more necessary that the trans-border extent (China-Nepal) of some GLOFs damages requires international cooperation (ICIMOD 2011).

\subsubsection{INCREASE OF CATASTROPHIC FLOODS IN THE MOUNTAIN AND HIMALAYAN FOOTHILLS?}

Apart from the GLOFs that distinctively affect the high, glaciated valleys, climate change may also involve changes in the frequency and magnitude of extreme events further downvalley. Other hazards such as landslide, debris flows and flash flood events seem to have recently increased in the Middle Himalayas, some of them with chain reaction impacts propagating as far as down to the Himalayan foothills.

Himalayan foothills are subject to large, devastating floods generated by rains exceptional in their intensity and abundance, comparable to what Starkel (1972) studied in the Darjeeling Himalayas in 1968. For instance, in July 1993 very localized, extreme precipitation (65 $\mathrm{mm} / \mathrm{h},>500 \mathrm{~mm} / 24 \mathrm{~h}$ ) in the upper Bagmati catchment (south of Kathmandu) increased the discharge of the river from $161 \mathrm{~m}^{3} \mathrm{~s}^{-1}$ to $11,700 \mathrm{~m}^{3} \mathrm{~s}^{-1}$ (flood return period of 66 years), carrying a solid load estimated to be $100 \mathrm{Mm}^{3}$ chiefly supplied by the lower hillslopes and river banks (Fort, 1997). In the gorge sections, the rising water mostly destroyed the veg- etation, whereas in wider sections of the Mahabharat range (Palung, Kitini and Markhu basins) and Siwalik-Terai foothills, several villages were severely destroyed: more than 1,000 people living in the foothills died, and losses totalled several million USD (a new irrigation plant was entirely damaged). Again in the Eastern Nepal Himalaya, in August 2008, the monsoon rains were so strong that the Kosi River discharge increased from an average of 30,000 up to 130,000 cubic metres per second, hence causing the failure of a man-made embankment of the Kosi River and the diversion of the river back to its $18^{\text {th }}$ century old channel. The waters flowed across the Nepal Himalayan foothills and the adjacent Bihar state (India): 2,000 people were killed, more than 300,000 houses were destroyed, 3,500 square kilometres devastated, and about 3 million of people were severely affected. Heavy monsoon rains also were at the origin of the catastrophic late July 2010 Indus floods, which put about one fifth of Pakistan's land under water, affected about 20 million people (death toll close to two thousands), and caused unprecedented economic damages (destruction of infrastructure and crops) amounting to 4.5 billion USD. Indeed, all these recent events have to be considered as snapshots of what is a long-term process (avulsion, an integral part of the construction of Himalayan mega-fans) that has taken place repeatedly along the Himalayan foothills for the past 18 million years, as recorded by the Siwalik molasse sediments, and shaped the Himalayan foothills.

Nowadays many changes have occurred: piedmont plains have become the wheat and rice granary for millions of people and offer the greatest potential for development (major irrigation projects, unlimited underground water reserves, well developed infrastructures); this explains their attractiveness and their rapid urbanization, hence their great vulnerability and high potential of losses when such an event does occur.

\subsubsection{TOWARDS WATER SHORTAGE?}

Global warming might well impact upon water resources, upon which depends the survival of mountain populations, especially 
those living in the driest parts, i.e. in the high valleys north of the Greater Himalayas. Different IPCC scenarios (Cruz et al., 2007) suggest that increased temperature will be accompanied by increased seasonal variability in precipitation. Lal (2002) stated that decreasing rainfall in winter and increasing rainfall in summer are expected, with an increased variability in the monsoon's onset.

More specifically, in the Middle Himalayas, models suggest that there will be a $30-50 \%$ reduction in dry season flow. This means that during the dry season, increase in evapotranspiration rates would result in a reduction of seasonal soil moisture and ground water storage, hence of spring yield, with reduced runoff. Collectively it will result in a higher pressure on water resource, all the more important that the irrigated agriculture, the economic and demographic growth together with higher living standard in urbanized zones cause a higher water demand (Merz et al., 2003). In addition, winter water deficit may directly affect both water quality and hydropower production, particularly in urbanized areas. In the Kathmandu valley, water shortage may reach critical levels during the end of the dry season, a situation that reinforces the man-induced pollution, e.g., the high degree of heavy metals and nitrates concentration and microbial contamination in the Bagmati watershed (Warner et al., 2008). Similarly during winter and spring, access to electricity is already restricted to only a few hours per day (low level of the Kulekhani reservoir fed by ground water flow), an important drawback that compromises Kathmandu economic development.

Conversely, during the rainy monsoon summer, an increased rainfall is expected (Christensen et al., 2007), hence an increased runoff and a higher susceptibility to flood generation and land degradation by water (as mentioned above). This, together with higher flood peak size, will primarily affect the Himalayan valleys, where a contrasted pattern of settlement and land-use change (abandoning of marginal, agricultural land $v s$ expansion of new urban centres along roads; Khanal and Watanabe, 2006) makes Himalayan population more vulnerable to any hillslope and/or river channel hazards (Fort et al., 2010). To a greater extent, this will also affect downstream societies.

Whatever the hydrological models used, all results obtained suggest that fair, sustainable water management options should be taken to reducing considerably the vulnerability to natural hazards and improving the quality of the water.

\section{CONCLUDING REMARKS}

The Himalayas are the highest mountains on Earth, characterized by intense geomorphic processes affecting mountain slopes, and adjacent river channels. Himalayan populations have always coped with a highly dynamic environment; for many generations, they have acquired an empirical knowledge and a good understanding of the most frequent hazards (landslides and floods) that may threaten them. Recent migrations of people attracted by the economic and social benefits associated with a large city or a new road have made the population much more vulnerable, because of their exposure to unfamiliar hazards that may occur in their new settlement. The impacts of global change, quite obvious in the high mountains, are more difficult to predict in the densely populated, middle Himalayas (i.e. behaviour of the monsoon) or in the foothills plains (large floods). The major disaster people would have to face is the conjunction of several hazards occurring at the same time. For instance, the occurrence of a large earthquake affecting the Himalayan mountains during the monsoon season would create a dreadful situation: triggering of many landslides, with their downstream chain reaction effects (combined secondary landslides, stream blockages and floods) and the probable difficult impediment to the rescue and recovery phase after the disaster, as illustrated by the aftermath of the 2008 Sichuan earthquake. Finally, water resource availability, either limited (droughts) or in excess (floods), is an important issue that may impact durably, economically and so- 
cially, the entire Nepal and adjacent India. Clearly, in a context of developing country and socio-economically vulnerable population, there should be no fatality to live permanently with such natural threats. Combining local and scientific knowledge, selecting simple local techniques of hazards control and mitigation, raising awareness collectively would help Nepali people to help themselves for a better life in their unique environment: they strongly deserve it!

\section{ACKNOWLEDGEMENTS}

This contribution is a tribute to Professor Leszek Starkel, a Himalayan mountain hydro-geomorphologist whose seminal papers on Darjeeling Himalayas were of great inspiration to me. Fieldwork in the Himalayas was supported by various CNRS and Paris-Diderot University research grants during the last 35 years. My warmest thanks go to my porters Man Bahadur Mangar, Gopal Mangar and Iman Singh Lama without whom any fieldwork in remote places would have been impossible. I also thank the many villagers who provided information on past geomorphic events, and the many friends and colleagues of Kathmandu Institutions (Department of Mines and Geology, Tri-Chandra Campus Tribhuvan University, Kirtipur University) for stimulating discussions and support. I am very grateful to F. Bétard (Univ. Paris-Diderot) for his help in finalizing illustrations, and to Pr. E. Derbyshire for his comments on an earlier draft of part of this text. Finally, I am deeply indebted to L. Bollinger (CEA-DASE, Bruyères-le-Chatel) and S. Sapkota (Head, National Seismological Centre Nepal, Kathmandu) who provided personal data and gave authorization to reproduce them.

\section{REFERENCES}

Adhikary, D.P. and Koshimizu, S. (2005), Debris flow disaster at Larcha, upper Bhotekoshi valley, Central Nepal, The Island Arc, 14: 410-423.
Alford, D. and Armstrong, R. (2010), The role of glaciers in stream flow from the Nepal Himalaya, The Cryosphere Discussion, 4: 469-494.

Armijo, R., Tapponnier, P., Mercier, J.-L. and Tonglin, H. (1986), Quaternary extension in southern Tibet: field observations and tectonic implications, Journal of Geophysical Research, 91: 13,803-13,872.

Avouac, J.P. and Burov, E. (1996), Erosion as a driving mechanism of intra- continental mountain growth, Journal of Geophysical Research, 101: 17,747-17,769, doi: 10.1029/96JB01344.

Bajracharya, S. and Mool, P. (2009), Glaciers, glacial lakes and glacial lake outburst floods in the Mount Everest region, Nepal, Annals of Glaciology, 50, 53: 81-86.

Bhandary, N.P., Yatabe, R., Hasegawa, S., Inagaki, H. and Shrestha, H.K. (2008), Characteristic features of landslides in the vicinity of major road network in Central Nepal, in Casagli, N., Fanti, R. and V. Fanti, V. (eds.), Web Proceedings of The First World Landslide Conference (18-21 Nov. 2008, Tokyo), Parallel session volume, pp. 326-329.

Bilham, R. and Wallace, K. (2005), Future Mw > 8 earthquakes in the Himalaya: implications from the 26 Dec. $2004 \mathrm{Mw}=9.0$ earthquake on India's eastern plate margin, Geological Survey of India Special Publication, 85: 1-14.

Bollinger, L., Avouac, J.-P., Beyssac, O., Catlos, E. J., Harrison, T. M., Grove, M., Goffé, B. and Sapkota, S. (2004a), Thermal structure and exhumation history of the lesser Himalaya, Tectonics, TC5015, doi:10.1029/2003TC001564.

Bollinger, L., Avouac, J.-P., Cattin, R. and Pandey, M. R. (2004b), Stress buildup in the Himalaya. Journal of Geophysical Research, 109, B11405, doi:10.1029/2003JB002911.

Bollinger, L., Henry, P. and Avouac, J.-P. (2006), Mountain building in the Nepal Himalaya: Thermal and kinematic model, Earth and Planetary Science Letters, 244: 58-71.

Bookhagen, B. and Burbank, D.W. (2010), Towards a complete Himalayan hydrological budget: The spatiotemporal distribution of snowmelt and rainfall and their impact on river discharge, Journal of Geophysical Research, 115, FO3019, doi:10.1029/2009JF001426, 2010 
Brunsden, D. and Jones, D.K.C. (1984), The geomorphology of high magnitude-low frequency events in the Karakoram mountains, in Miller, K.J. (ed.), The International Karakoram Project, v. 1, Cambridge University Press, Cambridge, 383-388.

Brunsden, D., Jones, D.K.G., Doornkamp, J.C. and Martin, R.P. (1981), The geomorphological character of part of the Low Himalaya of Eastern Nepal, Zeitschrift für Geomorphologie, N.F., Supplement-Band, 37: 25-72.

Burbank, D.W. and Johnson, G. (1983), The late Cenozoic chronologic and stratigraphic development of the Kashmir intermontane basin, Northwestern Himalaya, Palaeogeography, Palaeoclimatology, Palaeoecology, 43, 3-4: 205-235

Caine, N. and Mool, P.K. (1982), Landslides in the Kolpu Khola drainage, Middle Mountains, Nepal, Mountain Research and Development, 2: 157-173.

Carson, B. (1985), Erosion and sedimentation processes in the Nepal Himalaya, ICIMOD Occasional Paper No.1, Kathmandu (Nepal), $39 \mathrm{p}$.

Cenderelli, D.A. and Wohl, E.E. (2003), Flow hydraulics and geomorphic effects of glacial-lake outburst floods in the Mount Everest region, Nepal, Earth Surface Processes and Landforms, 28: 385-407.

Christensen, J.H., Hewitson, B., Busuioc, A., Chen, A., Gao, X., Held, I., Jones, R., Kolli, R. K., Kwon, W.-T., Laprise, R., Magana Rueda, V., Mearns, L., Menendez, C. G., Raisanen, J., Rinke, A., Sarr, A. and Whetton, P. (2007), Regional Climate Projections, in Solomon, S., Qin, D., Manning, M. et al. (eds), Climate Change 2007: The Physical Science Basis. Contribution of Working Group I to the Fourth Assessment Report of the Intergovernmental Panel on Climate Change, Cambridge University Press, Cambridge, UK and New York, USA.

Colchen, M., Le Fort, P., and Pêcher, A. (1986), Annapurna, Manaslu, Ganesh Himal (with 1: 200.000 geological map), Paris, CNRS Editions, $136 \mathrm{pp}$.

Cruz, R.V., Harasawa, H., Lal, M., Wu, S., Anokhin, Y., Punsalmaa, B., Honda, Y., Jafari, M., Li, C. and Huu Ninh, N. (2007),
Asia, in Parry, M. L., Canziani, O. F., Palutikof, J. P., van der Linden P. J., and Hanson, C. E. (eds.), Climate Change 2007: Impacts, Adaptation and Vulnerability. Contribution of Working Group II to the Fourth Assessment Report of the Intergovernmental Panel on Climate Change, Cambridge University Press, Cambridge, UK, 469-506.

Dahal, R.K., Hasegawa, S., Yamanaka, M., Bhandary, N.P. and Yatabe, R. (2006), Role of monsoon rainfall on landsliding in Nepal, Proceedings of the International Symposium on Landslide Hazards in Orogenic Zone from the Himalaya to Island Arc in Asia, 1-4.

Dahal, R.K. and Hasegawa, S. (2008), Representative rainfall thresholds for landslides in the Nepal Himalaya, Geomorphology, 100: 429-443.

Delcaillau, B. (1992), Les Siwaliks de l'Himalaya du Népal Oriental, CNRS, Mémoires et Documents de Géographie, 205 p.

Dollfus, O. and Fort, M. (2003), Sur quelques éléments structurants de la montagne himalayenne, in Smadja, J. (ed.), Histoire et devenir des paysages en Himalaya. Représentations des milieux et gestion des ressources au Népal et au Ladakh, CNRS Editions, Paris, 113-141.

Dunning, S.A., Rosser, N.J., Petley, D.N. and Massey, C.I. (2006), The formation and failure of the Tsatichhu landslide dam, Bhutan Himalaya, Landslides, 3: 107-113.

Dyurgerov, M. and Meier, MF. (2005), Glaciers and the changing earth system. A 2004 snapshot, Occasional Paper, 58, Arctic and Alpine Research, University of Colorado, Boulder (Co), $118 \mathrm{p}$.

Ekholm, E. P. (1976), Losing Ground: Environmental Stress and World Food Prospects, W. Norton and Co, New York.

Fort, M. (1987), Sporadic morphogenesis in a continental subduction setting: an example from the Annapurna Range, Nepal Himalaya, Zeitschrift für Geomorphologie, N.F. Supplement-Band, 63: 9-36.

Fort, M. (1988), Catastrophic sedimentation and morphogenesis along the High Himalayan Front, implications for palaeoenvironmental reconstructions, in Whyte, P., Aigner, J.S., Jablonski, N.G., Taylor, G., Walker, D. and Wang, P. (Eds), The Palaeoenvironment of 
East Asia from Mid-Tertiary. Proceedings of the Second International Conference, Centre of Asian Studies Occasional Papers and Monographs, 77, University of Hong Kong, 170-194.

Fort, M. (1997), Développement et aléas naturels dans l'Himalaya du Népal : la crue de Juillet 1993, bassin versant de la Bagmati, Géomorphologie, 1: 43-58.

Fort, M. (2000a), Glaciers and mass wasting processes: their influence on the shaping of the Kali Gandaki valley (Higher Himalaya of Nepal), Quaternary International, 65/66: 101-119.

Fort, M. (2000b), Physical conditions and constraints for irrigation in the dry Himalaya: an example from Upper Mustang (Nepal), in Kreutzmann, H. (Ed.), Water in Asia, Oxford University Press, Karachi, 239-258.

Fort, M. (2010), Pokhara valley (Nepal): a product of a natural catastrophe. in Migon, P. (ed.), Geomorphological Landscapes of the World, Springer Verlag, 27: 265-274.

Fort, M. (2011), Two large late Quaternary rock slope failures and their geomorphic significance, Annapurna Himalayas (Nepal), Geografia Fisica e Dinamica Quaternaria, 34, 1: 5-16.

Fort, M., Freytet P. and Colchen, M. (1982), Structural and sedimentological evolution of the Thakkhola-Mustang Graben (Nepal Himalaya), Zeitschrift für Geomorphologie, N.F. Supplement-Band, 42: 75-93.

Fort, M., Cossart, E. and Arnaud-Fassetta, G. (2010), Hillslope-channel coupling in the Nepal Himalayas and threat to man-made structures: the middle Kali Gandaki valley, Geomorphology, 124, 3-4: 178-199.

Fort, M. and Peulvast, J.-P. (1995), Catastrophic mass-movements and morphogenesis in the Peri-Tibetan Ranges: examples from West Kunlun, East Pamir and Ladakh, in Slaymaker, O. (ed.), Steepland Geomorphology, Wiley, Chichester, 171-198.

France-Lanord, C. and Derry, L.A. (1997), Organic carbon burial forcing of the carbon cycle from Himalayan erosion, Nature, 390, 6 November: 65-67.

Froehlich, W. and Starkel, L. (1987), Normal and extreme monsoon rains - their role in the shaping of the Darjeeling Himalaya, Studia Geomorphologica Carpatho-Balcanica, 21:129-160.
Gabet, E.J., Burbank, D.W., Putkonen, J.K., Pratt-Sitaula, B.A. and Ojha, T. (2004), Rainfall thresholds for landsliding in the Himalayas of Nepal, Geomorphology, 63: 131-143.

Gansser, A. (1964), Geology of the Himalayas, Wiley Interscience, London, $289 \mathrm{p}$.

Gerrard, A.J. (1994). The landslide hazard in the Himalayas; geological control and human action, Geomorphology, 10: 221-230.

Godin, L. (2003), Structural evolution of the Tethyan sedimentary sequence in the Annapurna area, central Nepal Himalaya, Journal of Asian Earth Sciences, 22: 307-328.

Hewitt, K. (2005), The Karakoram Anomaly? Glacier Expansion and the Elevation Effects, Karakoram Himalaya, Mountain Research and Development, 25, 4: 332-340.

Hewitt, K. (2009), Catastrophic rock slope failures and late Quaternary developments in the Nanga Parbat-Haramosh Massif, Upper Indus basin, northern Pakistan, Quaternary Science Reviews, 28: 1055-1069.

Hewitt, K., Clague, J.J. and Orwin, J.F. (2008), Legacies of catastrophic rock slope failures in mountain landscapes, Earth-Science Reviews, 87: $1-38$.

Hodges, K.V., Wobus, C., Ruhl, K. and Schildgen, T. (2004), Quaternary deformation, river steepening, and heavy precipitation at the front of the Higher Himalayan ranges, Earth and Planetary Science Letters, 220: 379-389.

International Centre for Integrated Mountain Development (ICIMOD) (2011), Glacial lakes and glacial lake outburst floods in Nepal, Kathmandu, 99 p.

Immerzeel, W.W., van Beek, L.P.H. and Bierkens, M.F.P. (2010), Climate Change will affect the Asian Water Towers, Science, 328: 1382-1385.

Ives, J.D. and Messerli, B. (1989), The Himalayan dilemma: reconciling development and conservation, United Nation University, Tokyo, Japan, London and New York, 285 p.

Khanal, N.R. and Watanabe, T. (2006), Abandonment of Agricultural Land and its Consequences; A Case Study in the Sikles Area, Gandaki Basin, Nepal Himalaya, Mountain Research and Development, 26, 1:32-40.

Korup, O. and Clague, J.J. (2009), Natural hazards, extreme events, and mountain topography, Quaternary Science Reviews, 28: 977-990. 
Kulkarni, A., Rathore, B.P., Singh, S.K. and Ajai, A. (2010), Distribution of seasonal snow cover in central and western Himalaya, Annals of Glaciology, 51(54): 121-128.

Lal, M. (2002), Possible impacts of Global Climate Change on Water availability in India. Report to Global Environment and Energy in the 21st Century, New Delhi: Indian Institute of Technology.

Lavé, J. and Avouac, J.P. (2001), Fluvial incision and tectonic uplift across the Himalaya of central Nepal, Journal of Geophysical Research, 106: 26,561-26,592, doi: 10.1029/2001JB000359.

Merz, J., Nakarmi, G., Shrestha, S.K., Dahal, B.M., Dangol, P.M., Dhakal, M.P., Dongol, B.S., Sharma, S., Shah, P.B. and Weingartner, R. (2003), Water: a Scarce Resource in Rural Catchments of Nepal's Middle Mountains, Mountain Research and Development, 23, 1: 41-49.

Métivier, F., Gaudemer, Y., Tapponnier, P. and Klein, M. (1999), Mass accumulation rates in Asia during the Cenozoic, Geophysical Journal International, 137: 280-318.

Molnar, P. and England, P. (1990), Late Cenozoic uplift of mountain ranges and global climate change: chicken or egg? Nature, 346: 29-34.

Molnar, P. and Tapponnier, P. (1975). Cenozoic tectonics of Asia: effects of a continental collision, Science, 189: 419-426.

Mool, P.K., Bajracharya, S.R. and Joshi, S.P. (2001), Inventory of glaciers, glacial lakes and glacial lake outburst floods, Nepal, ICIMOD and UNEP/RRC-AP, Kathmandu.

Naithani, A.K. (2001), The August, 1998 Okhimath tragedy in Rudraprayag district of Garhwal Himakaya, Uttaranchal, India, Gaia, 16: 145-156.

Nakata, T. (1972), Geomorphic history and crustal movements of the foothills of the Himalayas, Scientific Reports of the Tohoku University, Geography Department, 22: 177 p.

National Seismological Centre Nepal (2006), Epicentre Map of Nepal Himalaya (1994-2005), 1:1,000,000, NSC4, Department of Mines and Geology, Kathmandu, Nepal.

Oven, K., Petley, D., Rigg, J., Dunn, C. and Rosser, N. (2008), Landslides, Livelihoods and Risk: Vulnerability and Decision-Making in
Central Nepal, in Casagli, N., Fanti, R. and Fanti, V. (eds.), Web Proceedings of The First World Landslide Conference (18-21 Nov. 2008, Tokyo), Parallel session volume: 236-240.

Paul, S.K., Bartarya, S.K., Rautela, P. and Mahajan, A.K. (2000), Catastrophic mass movement of 1998 monsoon at Malpa in Kali Valley, Kumaun Himalaya (India), Geomorphology, 35: 169-180.

Petley, D.N., Hearn, G.J., Hart, A., Rosser, N.J., Dunning, S.A., Oven, K. and Mitchell, W.A. (2007), Trends in landslide occurrence in Nepal, Natural Hazards, 43: 23-44.

Raymo, M. E., and Ruddiman, W. F. (1992), Tectonic forcing of late Cenozoic climate, Nature, 359: 117-122.

Seeber, L. and Armbruster, J. (1981), Great detachment earthquakes along the Himalayan arc and long-term forecasting, in Simpson, D.W. and Richards, P.G. (eds.), Earthquake prediction: An international Review, Maurice Ewing Series, American Geophysical Union, Washington D.C., 4: 259-277.

Seeber, L. and Gornitz, V. (1975), River profiles along the Himalayan arc as indicators of active tectonics, Tectonophysics, 92: 335-367.

Starkel, L. (1972), The role of catastrophic rainfall in the shaping of the relief of the lower Himalaya (Darjeeling Hills), Geographia Polonica, 21: 103-160.

Starkel, L. (1976), The role of extreme (catastrophic) meteorological events in the contemporary evolution of slopes, in Derbyshire, E. (ed.), Geomorphology and Climate, J. Wiley, 213-246.

Starkel, L. and Subhashranjan, B. (eds.), (2000), Rains, Landslides and Floods in the Darjeeling Himalaya, Indian National Science Academy, $168 \mathrm{p}$.

Thayyen, R.J. and Gergan, J.T. (2010), Role of glaciers in watershed hydrology: a preliminary study of a "Himalayan catchment", The Cryosphere, 4: 115-128.

Valdyia, K.S. (1998), Dynamic Himalaya, University Press, Hyderabad (India), 178 p.

Vuichard, D. and Zimmermann, M. (1987), The 1985 catastrophic drainage of a moraine-dammed lake, Khumbu Himal, Nepal. Causes and consequence, Mountain Research and Development, 7: 91-110. 
Warner, N.R., Levy, J., Harpp, K. and Faruggia, F. (2008), Drinking water quality in Nepal's Kathmandu Valley: a survey and assessment of selected controlling site characteristics, Hydrogeology Journal, 16: 321-334

Watanabe, T., Lamsal, D. and Ives, J.D. (2009), Evaluating the growth characteristics of a glacial lake and its degree of danger of outburst flooding: Imja Glacier, Khumbu Himal, Nepal, Norsk Geografisk Tidsskrift-Norwegian Journal of Geography, 63: 255-267.

Weidinger, J.T. and Ibetsberger, H. (2000), Landslide dams of Tal, Latamrang, Ghatta Khola,
Ringmo, and Darbang in the Nepal Himalayas and related hazards, Journal of Nepal Geological Society, 22: 371-380

Willett, S.D. (1999), Orogeny and orography: The effects of erosion on the structure of mountain belts, Journal of Geophysical Research, 104: 28,957-28,981, doi: 10.1029/1999JB900248.

Paper first received: May 2011

In final form: July 2011 
http://rcin.org.pl 